\title{
GOVERNANCE THROUGH STOCK TRADING IN BRAZIL: EVIDENCE WITH INSTITUTIONAL INVESTORS
}

\author{
LUCAS N. C. VASCONCELOS 1 \\ (iD) https://orcid.org/0000-0003-2252-1950 \\ ORLEANS S. MARTINS \\ (iD) https://orcid.org/0000-0002-4966-0347
}

To cite this paper: Vasconcelos, L. N. C., \& Martins, O. S. (2020). Governance through stock trading in Brazil: Evidence with institutional investors. Revista de Administração Mackenzie, 21 (6), 1-31. doi:10.1590/1678-6971/eRAMD200046

Submission: Mar. 15, 2020. Acceptance: July 8, 2020.

Federal University of Paraíba (UFPB), João Pessoa, PB, Brazil.

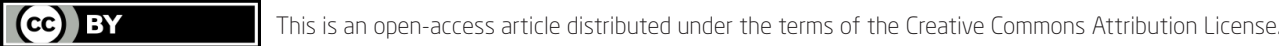

\footnotetext{
This paper may be copied, distributed, displayed, transmitted or adapted for any purpose, even commercially, if provided, in a clear and explicit way, the name of the journal, the edition, the year and the pages on which the paper was originally published, but not suggesting that RAM endorses paper reuse. This licensing term should be made explicit in cases of reuse or distribution to third parties.

Este artigo pode ser copiado, distribuído, exibido, transmitido ou adaptado para qualquer fim, mesmo que comercial, desde que citados, de forma clara e explícita, o nome da revista, a edição, o ano e as páginas nas quais o artigo foi publicado originalmente, mas sem sugerir que a RAM endosse a reutilização do artigo. Esse termo de licenciamento deve ser explicitado para os casos de reutilização ou distribuição para terceiros.
} 


\section{ABSTRACT}

Purpose: This paper analyses the viability of stock trading as a mechanism to promote corporate governance, addressing its effects on abnormal returns, information, and firm performance.

Originality/value: The study indicates that competition among institutional investors is important to raise stock price efficiency. Policies that allow capital inflow, increase in liquidity, and a link between managers' salaries and stock performance are beneficial to reinforce the stock market efficiency.

Design/methodology/approach: Hypotheses testing using panel data regressions of 233 stocks between December 2009 to December 2017 from Thomson Eikon, Economatica and ComDinheiro.

Findings: The results indicate that the number of institutional investors is not related to abnormal returns. On the other hand, the number of institutional investors increases the amount of firm-specific information into stock prices, rising stock market price efficiency. This relationship is stronger among the preferred stocks (PN), but this mechanism is still not valid to increase firms' operational performance. Despite the possible increase in stock price efficiency, the investors cannot adopt such a mechanism to exercise governance if there is no remuneration linked to performance.

\section{KEYWORDS}

Corporate governance. Exit. Stock price Informativeness. Institutional investor. Bid-ask spread. 


\section{INTRODUCTION}

After a series of negotiations, two companies, A and B, conclude that a merger will create value. The agreement is partially closed, but the investors of company $A$ believe that the company will not benefit from the agreement. They start to sell their stocks and to knock down prices considerably. In this scenario, there is a reduction in managers' pay for performance and the value to issue new stocks, and an increase in the takeover risk (Edmans \& Holderness, 2017).

Recent theories of corporate governance affirm that it is possible to exercise control by trading stocks or by liquidation threat (Edmans \& Manso, 2011). These theories merge with market microstructures literature by assuming that the trading activity of informed investors incorporates private information into prices, increasing market efficiency and operational performance (Edmans \& Holderness, 2017).

Most of these studies were conducted in developed markets, with strong legal property protection, proper disclosure, high stock liquidity, and low transaction costs (Edmans, Fang, \& Zur, 2013). In this sense, we tested some of the main implications of these theories, showing that they cannot be fully applied to an emerging market like Brazil.

The theory states that the effectiveness of governance though trading appears as an alternative in markets where capital is pulverized or when voting is not guaranteed for all investors (Edmans \& Manso, 2011). In Brazil, 34\% of firms with high governance levels have pulverized ownership. However, on other governance segments (level 2, level 1, and basic), this percentage is no more than $14 \%$. Also, there is voting rights concentration and a high level of non-voting shares (e. g., preferred stocks - PN) (KPMG, 2016). To the best of our knowledge, this is the first paper that addresses the topic of corporate governance through trading/threat of liquidation in Brazil.

To make the research feasible, we assumed that institutional investors are informed and that their property is large enough to guarantee intervention (McCahery, Sautner, \& Starks, 2016). We built three hypotheses based on the corporate governance literature.

- H1: The higher the competition between institutional investors, the smaller the abnormal stock returns.

- H2: The number of institutional investors has a positive relationship with the level of information on stock prices.

- H3: The higher the price efficiency promoted by institutional investors, the greater the operational performance. 
Empirical evidence before the theoretical development of Edmans and Manso (2011) had already been documented by Fang, Noe, and Tice (2009) and later by Gallagher, Gardner and Swan (2013). Our results indicate that only $\mathrm{H} 2$ can be strongly supported. But there is some evidence for $\mathrm{H} 3$.

These results have two implications. First, if the presence of institutional investors raises informational efficiency, policies that allow capital inflows are beneficial to the Brazilian stock market by generating significant synergies for the outsider investors, higher levels of performance, value creation (Fang et al. 2009) and default risk reduction (Brogaard, Li, \& Xia, 2017). Second, there is no evidence that a higher number of institutional investors lead to better performance if we do not consider the price efficiency level and the remuneration plan. Therefore, this study emphasizes that, to date, voting is the most efficient form of control in Brazil, which in turn is only functional when there is legal and property protection (Shleifer \& Vishny, 1986). These results give rise to conjectures that the lack of association between executive compensation and stock performance can mitigate potential efficiency gains and prevent governance through trading from being effective.

\section{BACKGROUND AND LITERATURE}

\subsection{Corporate governance and stock trading}

The control framework has two options available to investors to ensure firm value maximization: (i) they may impose management changes (known as "voice", "vote", or "direct intervention"); or (2) they may leave the company, liquidating their stocks. In the first option, corporate governance is exercised by voting. The ability to monitor the managers will depend on the number of stocks held, being proportional to the power of "voice" (Shleifer \& Vishny, 1986). The second line argues that governance can be exercised by alternative means, such as stocks trading and liquidation threats (Edmans \& Manso, 2011). Although diffuse property reduces the effectiveness of direct intervention by voting, it increases the efficiency of trading as a governance mechanism (Edmans \& Manso, 2011).

In this literature stream, a blockholder is a shareholder with informational advantage and sufficient power to induce intervention. Usually, they are institutional investors: banks, hedge funds and asset managers (McCahery et al., 2016). When management is inefficient, shareholders can sell their stocks to reduce stock prices and impact managers' salaries (when based on 
stock performance), raise takeover risks and undermine subsequent stock issues (Edmans \& Manso, 2011).

However, because they cannot coordinate trading orders to maximize the returns for all, they compete for the information advantage profit. This behavior increases the efficiency of the markets through the fast incorporation of information into prices, since each blockholder would issue orders with parts of the private information. The prices would reflect the company value and managerial performance (Edmans \& Manso, 2011). This governance mechanism happens more due to the threat of liquidation than by the actual trading: the stronger the ex-ante liquidation threat, the higher the likelihood that the manager will work to improve his results, reducing the need for ex-post liquidation (Edmans \& Holderness, 2017).

There is a limitation of such trading mechanism:

- if ownership increases, an informed blockholder can sell more shares upon collecting negative information about managers. But, if ownership becomes too large, selling the entire stock position becomes difficult because of the price impact;

- if ownership is too low, it could result in an insufficient power to discipline managers.

Most institutional investors in the United States claim that the threat of liquidation is only valid when they have at least $5-10 \%$ of the company's stocks (see McCahery et al., 2016, table IV). Figure 2.1.1 illustrates this counter effect, resulting in an optimal stake size and an optimal number of informed investors (McCahery et al., 2016).

\section{(Figure 2.1.1)}

INFORMATION COMPETITION AND ITS EFFECTS ON STOCK PRICE EFFICIENCY

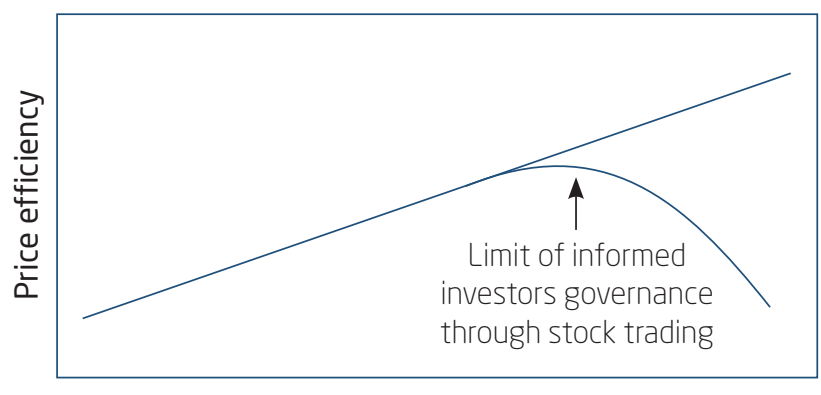

Informed investors competition

Source: Elaborated based on McCahery et al. (2016) 
In the empirical field, there is evidence that institutional investor trading is motivated by private information: the short-term trading of institutional investors anticipates future returns (Gallagher et al., 2013); their trading behavior anticipates the news and the accounting results (Hendershott, Livdan, \& Schürhoff, 2015). The days when there are institutional trades show abnormal returns (Collin-Dufresne \& Fos, 2015).

The role of institutional investors in the price informativeness is still an expanding field. On the one hand, there is evidence that institutional investors don't incorporate information into stock prices (Piotroski \& Roulstone, 2004). On the other hand, the presence of institutional investors increases the market efficiency by fast incorporation of firm-specific information (Gallagher et al., 2013; Brogaard et al., 2017; Dang, Nguyen, Tran, \& Vo, 2018).

Although scarce, there is conflicting evidence for the effectiveness of trading as a governance mechanism. Fang et al. (2009) present several tests to explain the relationship between liquidity and firm value. The authors conclude that, although institutional investors increase liquidity and, consequently, the market's informational efficiency, their presence doesn't explain the increase in the firms' performance. Brogaard et al. (2017) test if institutional investors reduce bankruptcy by increasing informational efficiency. The authors argue that, although it is not the best way to reduce bankruptcy, institutional investors help reduce this risk by intervening in strategic decisions.

Finally, there is evidence that countries' institutional factors affect the governance capacity of institutional investors. Evidence suggests that informed trading by institutional investors is rising in countries with less information transparency (poor disclosure infrastructure), low media coverage, poor governance and regulatory quality (Dang et al., 2018). In these countries, less public information can motivate institutional investors to acquire private information and execute profitable transactions (Dang et al., 2018). In Brazil, some stocks differ between governance and property protection regimes (KPMG, 2016). This scenario justifies the test in different classes of stocks in Brazilian stock market research.

\subsection{Stock price informativeness}

Stock price informativeness is defined as the amount of firm-specific information that is incorporated in prices (public or private) (Roll, 1988). Stock markets are vital to generating price signals to enhance investment allocation. If prices fully reflect fundamental values, such process occurs 
through two channels: 1 . capital is correctly priced and allows for the prediction of future cash flows; and 2. this information promotes feedbacks to managers (Edmans \& Manso, 2011).

The first channel is relevant in primary markets. If prices reflect the fundamentals, companies acquire fair financing. The second channel is more relevant in secondary markets, in which trading occurs among investors. Since there is no transfer of resources to firms, prices have consequences when they affect managers' decisions (Chen, Goldstein, \& Jiang, 2007).

The most common measure of price informativeness is the Roll's (1988) prices non-synchronicity: if firms' information level rises, there is an idea that the measure of the goodness of fit $\left(R^{2}\right)$ of a market model is inversely associated with the amount of firm-level information in stock prices. The explanation is that stock returns are driven by (i) systematic risk, (ii) changes in the market environment, and (iii) company-specific information. Therefore, greater availability of firm-specific information would reduce the stock returns synchrony and increase the price informativeness (Roll, 1988).

\subsection{Hypotheses}

Institutional investors are informed (Hendershott et al., 2015), and this increases the informational risk (Easley, Hvidkjaer \& O'Hara, 2002). However, because they cannot coordinate their orders to maximize the value for all stakeholders, informed investors compete for informational advantage profit (Edmans \& Manso, 2011) (H1):

- H1 (hypothesis of competition for information advantage): The higher the competition between institutional investors, the smaller the abnormal stock returns.

This behavior would increase market efficiency through the fast incorporation of firm-specific information. Prices would reflect more closely the firms' value (Edmans \& Manso, 2011) (H2):

- H2 (hypothesis of information production by trading): The number of institutional investors has a positive relationship with the level of information on stock prices.

The higher number of institutional investors will reduce the total ownership of each one of them. In this scenario, extreme ownership fragmentation may mitigate the strength of governance by trading. To account for this effect, we derived a sub hypothesis based on $\mathrm{H} 2$. 
- H2a: Stock Efficiency initially increases at a decreasing rate as the number of institutional investors increases, but it begins to decrease as this number continues to increase beyond a certain level, due to the reduction of intervention power, ceteris paribus.

If this type of governance is efficient, it is expected a positive effect on the companies' operational performance (Edmans \& Manso, 2011) (H3):

- H3 (hypothesis of governance through trading): The higher price efficiency promoted by institutional investors, the greater the operational performance.

Finally, evidence suggests that countries with less information transparency and poor corporate governance provide incentives for institutional investors to collect and trade using private information (Dang et al., 2018). In this case, although no hypotheses are drawn, the PN stocks were separated to conduct additional tests.

Besides that, the gain of efficiency from the institutional investors may not have a significant effect on the firms' performance because there are no efficient contracts that align managers' remuneration to stock returns (Edmans et al., 2013). According to Hofmeister (2018), the firms listed in the New Market (the segment of higher corporate governance in Brazil) have a payment ratio of BRL $\$ 4,500.00$ for $1 \%$ of shareholder return, while for other segments, the remuneration is not sensitive to returns. Again, although no hypotheses are drawn, we segmented the sample into two subsamples of high and low executive compensation to observe the effects.

\section{METHOD}

We dropped companies with no complete data in the Thomson Reuters Eikon and the Economatica databases from the years 2009 to 2017. The nonavailability of ownership data before 2009 justifies the data range. The executive compensation measure comes from the ComDinheiro.com database (see section 4.3.1). Panel A of Figure 3.1 shows the sample construction process. Panel B (panel C) shows firm distribution by sectors (by year). Financial institutions were excluded. The final sample had a total of 233 stocks and 1,597 valid observations (we used panel data).

To avoid outliers' biases, except for VROA (see Figure 3.4.1), we winsorized each variable by year at the bottom and top $2.5 \%$ of their distribution. If the VROA original value was higher (low) than the $97.5 \%(2.5 \%)$ 
percentile, the variable's value was changed to $100 \%(0 \%)$. The variance inflation factor test shows no multicollinearity problems. Hausman test points to fixed effects panel data. We applied clustered standard errors to overcome heteroscedasticity and autocorrelation problems.

\section{(Figure 3.1)}

\section{SAMPLE CONSTRUCTION AND DISTRIBUTION}

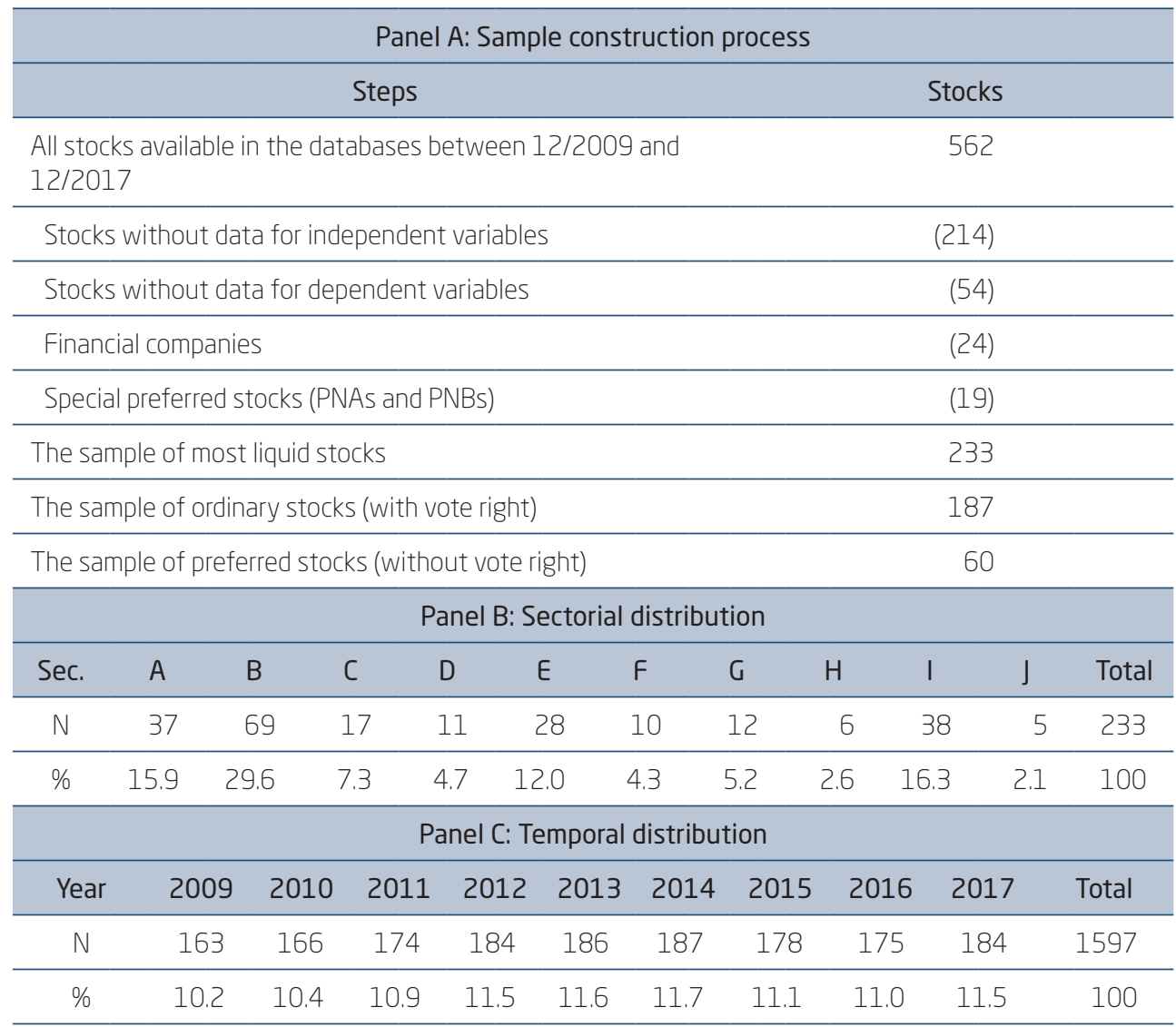

a Sectors: $A$ = industrial goods, $B=$ cyclical consumption, $C=$ non-cyclical consumption, $D=$ financial and others (banks and insurers are not included), $\mathrm{E}=$ basic materials, $\mathrm{F}=$ oil, gas and biofuels, $\mathrm{G}=$ health, $\mathrm{H}=$ information technology (IT), I = utility, and $\mathrm{J}=$ telecommunications.

Source: Elaborated by the authors.

\subsection{Institutional investors identification}

To construct the institutional investors' ownership measure, it is necessary to identify them. The data comes from Economatica. Since the institu- 
tional shareholder's National Register of Legal Entities (Cadastro Nacional de Pessoa Jurídica [CNPJ]) is not available in the database, we did a cross-reference of the investors' names with Economatica's fund database. After that, several institutions were left unidentified. To avoid underestimation, we used keywords to separate institutions apart from individuals (Figure 3.1.1). No shareholder was left unidentified.

(Figure 3.1.1)

KEYWORDS FOR INSTITUTIONAL INVESTORS IDENTIFICATION

\begin{tabular}{|c|c|}
\hline Investors & Keywords \\
\hline Investment Funds ${ }^{a}$ & $\begin{array}{l}\text { FIA, Banco, Bank, Banc, Equity, Equities, Hedge, Asset, } \\
\text { Management, Capital, Clube de, Foundation, Fl Mult, Research, } \\
\text { Group, Fund, Ações, Investment, Investments, Investimentos, } \\
\text { Gestão, Cred, Previ, Petros, Previdência, Pension, Partners, FIP, } \\
\text { FIA, Insurance. }\end{array}$ \\
\hline Foreign Investors ${ }^{b}$ & LIc, LIp, GmbH, Ltd, Inc, B.V, BV, Corporation. \\
\hline Holdings & Participações, Partic, Holding, Empreendimentos. \\
\hline Other companies ${ }^{c}$ & SA, S.A, S/A, Ltda. \\
\hline Government & Governo, Sec de Est, Estado, União, Estadual, BNDES, BNDESPar. \\
\hline
\end{tabular}

${ }^{a}$ Words associated with banks, asset managers, and pension funds; ${ }^{b}$ words associated with foreign companies; ' acronyms associated with limited liability companies.

Source: Elaborated by the authors.

\subsection{Institutional investor number and dispersion}

To test our hypotheses, we used two metrics: 1 . the number of institutional investors $(n l l)$ and 2 . the competition over information variable $(h l l)$, proposed by Akins, Ng and Verdi (2012). Equation 1 defines the variable $n l l$.

$$
\ln (n I I)=\ln (\text { Number of institutional investors) }
$$

The number of institutions (nII) also does not consider the ownership dispersion. Therefore, we adopted the competition proxy for information proposed by Akins et al. (2012) (in equation 2), for each stock $i$ in year $t$ : hII is the proxy for competition for information; $p I I_{i, t}$, the total institutional shareholding; and $p I_{i, j, t}$, the institutional investor ownership $j$ in stock $i$ in year $t$. 


$$
h I I_{i, t}=-1 \times \sum_{j=1}^{n I I}\left(\frac{p I I_{i, j, t}}{p I I_{i, t}}\right)^{2}
$$

\subsection{Information flow and performance variables}

We adopted the price non-synchronicity as a measure of price informativeness, following Chan and Hameed (2006). For each stock $i$ in year $t$, we: 1. apply the regression model of equation 3 , by ordinary least squares (OLS), with daily data; 2 . extract the adjusted coefficient of the goodness of fit $\left(R^{2}\right)$, and 3. use a logistic transformation in the variable (in equation 4$), r_{i, d}$ is the simple daily return of stock $i$ on day $d ; r M K T_{d}$, the daily return for the market portfolio proxy, the IBrX-100; $R^{2}$, is the adjusted coefficient of the goodness of fit of the equation 3 ; $\varepsilon$, the error term; and NSync, the price non-synchronicity of each stock $i$ in year $t$.

$$
\begin{gathered}
r_{i, d}=\alpha_{i, d}+\beta_{i}\left(r M K T_{d}\right)+\varepsilon_{i, d} \\
\left.N \operatorname{Sync}_{i, t}=\ln \left[\left(1-R_{i, t}^{2}\right) / R_{i, t}^{2}\right)\right]
\end{gathered}
$$

Following Gallagher et al. (2013), we adopted the low-frequency bid-ask spread proxy (BASP) as an alternative variable (equation 5). Based on Kyle's (1985), the bid-ask should reduce as the number of informed investors trading simultaneously increases. In equation 5 , in which BASP is the proxy for the bid-ask spread; $p$ is the maximum stock price $i$ on day $d ; p b$ is the minimum stock price $i$ on day $d . D$ is the number of days with valid observations for stock $i$ in year $t$ (i. e., when the transaction volume is non-zero).

$$
B A S P_{i, t}=\left(1 / D_{i, t}\right) \sum_{d=1}^{D_{i}} \frac{p s-p b}{\left(\frac{p s+p b}{2}\right)}
$$

Similar to Chen et al. (2007), we used return on assets $(R O A)$ as an operational performance metric. It was calculated as the ratio of $E B I T_{i, t}$ to TotalAssets $_{i, t-1}$.

To measure whether institutional investors are informed, information risk is defined as the abnormal return of each stock $i$ in year $t$ (CollinDufresne \& Fos, 2015). In equation 6 , in which, for each stock $i$ in year $t$ : 
$e$ Ret ${ }_{i, t}$ is the abnormal returns over the market index; and $r_{i, t}$ and $r M K T_{t}$ are the simple stock returns and the market returns of the IBrX-100, respectively.

$$
e \operatorname{Ret}_{i, t}=r_{i, t}-r M K T_{t}
$$

\subsection{Control variables and summary statistics}

Figure 3.3.1 describes the control variables and references. Comment on each effect was built on every hypothesis testing section.

(Figure 3.4.1)

CONTROL VARIABLES DESCRIPTION

\begin{tabular}{|c|c|c|}
\hline Controls & Variable definition & Main References \\
\hline Systematic risk (Beta) & $\begin{array}{l}\text { Calculated with the market model with one-year } \\
\text { daily returns. }\end{array}$ & $\begin{array}{l}\text { Morck, Yeung and Yu, } \\
2000\end{array}$ \\
\hline Firm size (a) (MV) & In of firm market capitalization & Easley et al. (2002) \\
\hline Firm size (TA) & In of total assets & Easley et al. (2002) \\
\hline Firm leverage (Debt) & Total debt to total capital & Gul, Kim and Oiu (2010) \\
\hline Market-to-book (M/B) & Market value of equity to book value of equity & Gul et al. (2010) \\
\hline $\begin{array}{l}\text { Enterprise value to operational } \\
\text { earnings ( } E V / E B / T)\end{array}$ & $\begin{array}{l}\text { The market value of equity plus book value of } \\
\text { debt to Ebit. }\end{array}$ & Gul et al. (2010) \\
\hline Profit volatility (VROA) & $\begin{array}{l}\text { Sample standard deviation of quarterly ROAs over } \\
\text { the last two years. This variable was truncated } \\
\text { between } 0 \text { and } 100 \text {. }\end{array}$ & Morck, et al. (2000) \\
\hline Analyst coverage (Analy) & The number of analysts who follow the company. & $\begin{array}{l}\text { Piotrosk and Roulstone } \\
\text { (2004) }\end{array}$ \\
\hline Stock trading volume (In(VOL)) & In of total stock trading volume. & Fang et al. (2009) \\
\hline $\begin{array}{l}\text { Number of days with zero } \\
\text { returns (Zeros) }\end{array}$ & $\begin{array}{l}\text { Number of days with zero returns in a year as a } \\
\text { fraction of annual trading days }\end{array}$ & Fang et al. (2009) \\
\hline
\end{tabular}

Source: Elaborated by the authors.

Figure 3.4.2 shows the descriptive statistics for ordinary stocks (panel A) and preferred stocks (panel B). A typical ordinary stock (ON) has an annual $3.5 \%$ bid-ask spread $(B A S P)$, is monitored by four or five analysts, is from a growing company with low systematic risk $($ Beta $<1)$, and has approximately four institutional investors. The preferred stocks (PN) already have a 3.3\% 
bid-ask spread (BASP), are monitored by two or three analysts, are from companies in low-beta growth, with three institutional investors.

(Figure 3.4.2)

SAMPLE DESCRIPTIVE STATISTICS

\begin{tabular}{|c|c|c|c|c|c|c|}
\hline Variable & & Mean & Median & SD & Min. & Max. \\
\hline \multicolumn{7}{|c|}{ Panel A - sample of ON stocks } \\
\hline Abnormal returns (\%) & eRet & 8.928 & -0.065 & 57.901 & -123.265 & 483.488 \\
\hline Analyst coverage & Analy & 4.874 & 3.000 & 5.157 & 0.000 & 18.000 \\
\hline Bid-ask spread (\%) & BASP & 3.525 & 3.290 & 2.202 & 0.000 & 48.309 \\
\hline Firm value to Ebit & EV/EBIT & 10.441 & 10.809 & 21.594 & -119.775 & 113.487 \\
\hline Financial leverage & Debt & 42.475 & 42.662 & 23.725 & 0.000 & 99.472 \\
\hline Market capitalization & $\ln (M v)$ & 14.482 & 14.648 & 1.793 & 7.812 & 19.751 \\
\hline Market-to-book & $\ln (M / B)$ & 0.323 & 0.363 & 1.050 & -2.941 & 4.513 \\
\hline No. of institutional investors & $n / l$ & 3.809 & 4.000 & 2.676 & 0.000 & 26.000 \\
\hline Ownership dispersion & hll & -48.426 & -45.881 & 29.199 & -100.000 & 0.000 \\
\hline Price non-synchronicity & NSyns & 2.637 & 2.175 & 1.965 & -0.024 & 9.775 \\
\hline Executive variable payment (\%) & Remu & 10.612 & 0.000 & 17.937 & 0.000 & 99.566 \\
\hline Return on assets (\%) & $R O A$ & 7.567 & 7.493 & 10.505 & -90.249 & 60.557 \\
\hline ROA volatility & VROA & 3.713 & 2.046 & 7.602 & 0.000 & 100.000 \\
\hline Systematic risk & Beta & 0.583 & 0.536 & 0.420 & -1.871 & 3.903 \\
\hline Total assets & $\ln (T A)$ & 22.136 & 22.065 & 1.614 & 16.546 & 27.525 \\
\hline Total of zero returns (\%) & Zeros & 13.033 & 5.220 & 18.310 & 0.000 & 89.837 \\
\hline Trading volume & $\ln (V O L)$ & 13.109 & 13.477 & 2.634 & 3.216 & 18.305 \\
\hline \multicolumn{7}{|c|}{ Panel B - sample of PN stocks } \\
\hline Abnormal returns (\%) & eRet & 2.974 & -4.163 & 47.038 & -121.539 & 230.903 \\
\hline Analyst coverage & Analy & 2.987 & 0.000 & 4.968 & 0.000 & 16.000 \\
\hline Bid-ask spread (\%) & BASP & 3.340 & 2.879 & 3.598 & 0.000 & 51.935 \\
\hline Firm value to Ebit & EV/EBIT & 9.200 & 7.989 & 20.170 & -93.222 & 113.487 \\
\hline Financial leverage & Debt & 40.860 & 41.108 & 26.835 & 0.000 & 99.543 \\
\hline Market capitalization & $\ln (M v)$ & 13.157 & 13.153 & 2.371 & 8.032 & 18.896 \\
\hline
\end{tabular}




\section{(Figure 3.4 .2 (conclusion))}

SAMPLE DESCRIPTIVE STATISTICS

\begin{tabular}{lcrrrrr}
\hline \multicolumn{1}{c}{ Variable } & \multicolumn{2}{c}{ Mean } & Median & SD & Min. & Max. \\
\hline & Panel B - sample of PN stocks & & & \\
\hline Market-to-book & In(M/B) & -0.465 & -0.488 & 1.017 & -2.941 & 3.649 \\
\hline No. of institutional investors & nll & 3.820 & 3.000 & 3.425 & 0.000 & 25.000 \\
\hline Ownership dispersion & hll & -43.862 & -40.405 & 31.346 & -100.000 & 0.000 \\
\hline Price non-synchronicity & NSyns & 3.414 & 2.985 & 2.477 & -0.024 & 9.775 \\
\hline Executive variable payment (\%) & Remu & 12.592 & 0.000 & 17.429 & 0.000 & 56.357 \\
\hline Return on assets (\%) & ROA & 6.679 & 6.704 & 10.351 & -48.240 & 100.742 \\
\hline ROA volatility (\%) & VROA & 3.477 & 2.106 & 5.032 & 0.000 & 48.773 \\
\hline Systematic risk & Beta & 0.506 & 0.464 & 0.594 & -7.058 & 1.981 \\
\hline Total assets & In(TA) & 21.808 & 21.938 & 2.066 & 17.057 & 27.525 \\
\hline Total of zero returns (\%) & Zeros & 25.870 & 11.788 & 26.936 & 0.000 & 93.089 \\
\hline Trading volume & $\operatorname{In}($ VOL) & 11.603 & 11.129 & 3.389 & 4.440 & 19.059 \\
\hline
\end{tabular}

Source: Elaborated by the authors.

\section{RESULTS}

\subsection{Competition between institutional investors and abnormal returns}

We applied the regression model of equation 7 to test H1, in which, for each stock $i$ in year $t$, eRet is the abnormal return variable, II represents the multiple institutional investors' competition (nII or hII). RiskControls are the variables associated with risk factors: the stock beta (Beta), to control for market risk; market value of equity $((\operatorname{In}(M V))$ to control for small firms' effect; Market-to-book $(\operatorname{In}(M / B))$ to control for the value effect; Financial Leverage (Debt), to control for the leverage effect; The number of days with zero returns (Zeros) to control for illiquidity effect; and Analyst Coverage (In(Analy)) to control for informational effect (Girão, 2016).

$$
\text { Ret }_{i, t}=\beta_{0}+\beta_{1} I I_{i, t}+\sum_{k} \beta_{k} \text { RiskControls }_{i, t}+\varepsilon_{i, t}
$$


According to the estimated coefficients (Figure 4.1.1), it is not possible to affirm that the competition among institutional investors (nII and hII) reduces the abnormal returns. Girão (2016) reported similar results: there is no relation between the number of institutions and the reduction on cost of capital. So, not all institutional investors may be informed investors. These findings are different compared to the United States' market (Akins et al., 2012).

\section{(Figure 4.1.1)}

\section{THE NUMBER OF INSTITUTIONAL INVESTORS AND ABNORMAL RETURNS}

\begin{tabular}{|c|c|c|c|c|c|c|}
\hline \multirow{4}{*}{$\begin{array}{c}\text { Independent } \\
\text { variables }\end{array}$} & \multicolumn{6}{|c|}{ Dependent variable: eRet } \\
\hline & \multicolumn{6}{|c|}{$\mathrm{H} 1: \beta_{1}(I I)<0$} \\
\hline & \multicolumn{3}{|c|}{$I I=\ln (n I I)$} & \multicolumn{3}{|c|}{$\|=h\|$} \\
\hline & $\begin{array}{l}\text { The most } \\
\text { liquid ones } \\
\text { (1) }\end{array}$ & $\begin{array}{c}\text { ON } \\
\text { stocks } \\
(2)\end{array}$ & $\begin{array}{c}\text { PN } \\
\text { stocks } \\
(3)\end{array}$ & $\begin{array}{l}\text { The most } \\
\text { liquid ones } \\
\text { (4) }\end{array}$ & $\begin{array}{c}\text { ON } \\
\text { stocks } \\
(5)\end{array}$ & $\begin{array}{c}\text { PN } \\
\text { stocks } \\
(6)\end{array}$ \\
\hline 11 & $\begin{array}{l}1.984 \\
(0.40)\end{array}$ & $\begin{array}{l}5.636 \\
(1.04)\end{array}$ & $\begin{array}{l}-4.508 \\
(-0.47)\end{array}$ & $\begin{array}{l}-0.058 \\
(-0.69)\end{array}$ & $\begin{array}{l}-0.048 \\
(-0.49)\end{array}$ & $\begin{array}{l}-0.081 \\
(-0.65)\end{array}$ \\
\hline Beta & $\begin{array}{l}8.218 * \\
(1.65)\end{array}$ & $\begin{array}{l}9.152 \\
(1.50)\end{array}$ & $\begin{array}{l}7.461 \\
(1.16)\end{array}$ & $\begin{array}{l}8.213 \\
(1.66)\end{array}$ & $\begin{array}{l}9.343 \\
(1.54)\end{array}$ & $\begin{array}{l}8.139 \\
(1.18)\end{array}$ \\
\hline $\ln (M V)$ & $\begin{array}{l}8.619 * \\
(1.93)\end{array}$ & $\begin{array}{l}7.633 \\
(1.54)\end{array}$ & $\begin{array}{c}16.318^{\text {** }} \\
(2.64)\end{array}$ & $\begin{array}{l}8.668 \\
(1.95)\end{array}$ & $\begin{array}{l}7.609 \\
(1.55)\end{array}$ & $\begin{array}{c}16.667^{\text {*** }} \\
(2.76)\end{array}$ \\
\hline $\ln (M / B)$ & $\begin{array}{c}32.759 * * * \\
(6.33)\end{array}$ & $\begin{array}{c}36.485 * * * \\
(6.53)\end{array}$ & $\begin{array}{c}16.002^{* *} \\
(2.36)\end{array}$ & $\begin{array}{c}32.723 \\
(6.37)\end{array}$ & $\begin{array}{c}36.369 * * * \\
(6.58)\end{array}$ & $\begin{array}{c}15.645^{* *} \\
(2.24)\end{array}$ \\
\hline Debt & $\begin{array}{c}-0.777^{\star \star \star} \\
(-3.99)\end{array}$ & $\begin{array}{c}-0.926 * \star \star \\
(-4.09)\end{array}$ & $\begin{array}{l}-0.183 \\
(-0.68)\end{array}$ & $\begin{array}{l}-0.775 \\
(-4.00)\end{array}$ & $\begin{array}{c}-0.916 \text { *** } \\
(-4.07)\end{array}$ & $\begin{array}{l}-0.190 \\
(-0.72)\end{array}$ \\
\hline Zeros & $\begin{array}{l}-0.315 \\
(-1.62)\end{array}$ & $\begin{array}{l}-0.517^{\star \star} \\
(-2.24)\end{array}$ & $\begin{array}{l}0.087 \\
(0.36)\end{array}$ & $\begin{array}{l}-0.324 \\
(-1.67)\end{array}$ & $\begin{array}{c}-0.525 * \star \\
(-2.26)\end{array}$ & $\begin{array}{l}0.090 \\
(0.37)\end{array}$ \\
\hline $\ln ($ Analy) & 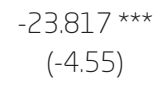 & $\begin{array}{c}-26.023^{* \star *} \\
(-4.95)\end{array}$ & $\begin{array}{c}-14.784 \\
(-1.07)\end{array}$ & $\begin{array}{l}-23.727 \\
(-4.53)\end{array}$ & $\begin{array}{c}-25.599 \text { *** } \\
(-4.82)\end{array}$ & $\begin{array}{c}-13.870 \\
(-1.02)\end{array}$ \\
\hline Fixed eff. $(i, t)$ & Yes & Yes & Yes & Yes & Yes & Yes \\
\hline Observations & 1,597 & 1,304 & 400 & 1,597 & 1,304 & 400 \\
\hline Individuals & 233 & 191 & 60 & 233 & 191 & 60 \\
\hline Within- $R^{2}$ & $23.48 \%$ & $28.64 \%$ & $16.68 \%$ & $23.50 \%$ & $28.25 \%$ & $16.64 \%$ \\
\hline
\end{tabular}

$*$, **, and *** indicate significance at 10\%, $5 \%$, and $1 \%$, respectively.

Source: Elaborated by the authors. 
The controls followed what is commonly documented in the national asset pricing literature: Beta is positive in all regressions, Size and $M / B$ show a positive relationship, similar to the Brazilian evidence (Cordeiro \& Machado, 2013), but in disagreement with the United States' market findings (Fama \& French, 2006). The Debt shows a negative effect (Cordeiro \& Machado, 2013). The investment analyst's coverage is negative, similar to Girão's (2016).

Finally, as a robustness test, we use other firm size and valuation measures to account for some mechanical correlations between $M / B, M V$, and eRet. We use the $\ln$ of total assets $(\operatorname{In}(T A))$ as an alternative measure of firm size and EV / EBIT measure of valuation. Again, measures of institutional investor's competition do not show any relationship with eRet. The size measure changes its coefficient and shows a negative relationship with abnormal returns. In this way, this relationship may be capturing the asset growth effect (Fama \& French, 2006). The new value measure has an insignificant coefficient.

\subsection{Institutional investors and the price informativeness}

We used the regression model of equation 8 to test $\mathrm{H} 2$. Where, for each stock $i$ in year $t$, IE is the information efficiency proxy: NSync or BASP. Control is the vector of control variables: size $(\operatorname{In}(M V))$, market-to-book $(\operatorname{In}(M / B))$, financial leverage (Debt), ROA volatility (VROA) and analyst coverage $(\operatorname{In}($ Analy $))$. It is expected that II has a positive coefficient with NSync and a negative one with BASP.

$$
I E_{i, t}=\beta_{0}+\beta_{1} I I_{i, t}+\sum_{k} \beta_{k} \text { Control }_{i, t}+\varepsilon_{i, t}
$$

Figure 4.2.1 presents the estimated coefficients of equation 8. In panel A, we can see that in the sample of liquid stocks (columns 1), when the dependent variable is NSync, hypothesis H2 is not confirmed. However, we have evidence that institutional investors reduce bid-ask spreads (column 4). In the ON stocks sample, $n I I$ loses statistical significance (column 5). We can see that the signs reported in the complete sample come from PN stocks: in columns 3 and 6 , there is evidence that the higher the number of institutional investors $(n I I)$ the greater the incorporation of private information into stock prices, either by increasing NSync or by reducing the bid-ask spread $(B A S P)$. These findings support the international literature that the presence of institutional investors raises the levels of informational efficiency (Dang et al., 2018). 


\section{(Figure 4.2.1)}

INSTITUTIONAL INVESTORS AND THE INFORMATION FLOW

\begin{tabular}{|c|c|c|c|c|c|c|}
\hline \multicolumn{7}{|c|}{ Panel A - Institutional investors and the information flow $(I I=\ln (n I I))$} \\
\hline \multirow{3}{*}{$\begin{array}{l}\text { Independent } \\
\text { variables }\end{array}$} & \multicolumn{3}{|c|}{ Dependent variable: NSync } & \multicolumn{3}{|c|}{ Dependent variable: BASP } \\
\hline & \multicolumn{3}{|c|}{$\mathrm{H} 2: \beta_{1}>0$} & \multicolumn{3}{|c|}{$\mathrm{H} 2: \beta_{1}<0$} \\
\hline & $\begin{array}{l}\text { The most } \\
\text { liquid ones } \\
\text { (1) }\end{array}$ & $\begin{array}{l}\text { ON } \\
\text { stocks } \\
(2)\end{array}$ & $\begin{array}{c}\text { PN } \\
\text { stocks } \\
(3)\end{array}$ & $\begin{array}{l}\text { The most } \\
\text { liquid ones } \\
\text { (4) }\end{array}$ & $\begin{array}{c}\text { ON } \\
\text { stocks } \\
(5)\end{array}$ & $\begin{array}{c}\text { PN } \\
\text { stocks } \\
(6)\end{array}$ \\
\hline $\ln (n / l)$ & $\begin{array}{l}0.032 \\
(0.42)\end{array}$ & $\begin{array}{l}-0.054 \\
(-0.63)\end{array}$ & $\begin{array}{c}0.381 \text { ** } \\
(2.57)\end{array}$ & $\begin{array}{c}-0.250 * * \\
(-2.34)\end{array}$ & $\begin{array}{l}-0.123 \\
(-1.18)\end{array}$ & $\begin{array}{l}-0.483 \text { * } \\
(-1.89)\end{array}$ \\
\hline $\ln (\mathrm{MV})$ & $\begin{array}{l}-0.227^{*} \\
(-1.76)\end{array}$ & $\begin{array}{l}-0.157 \\
(-1.08)\end{array}$ & $\begin{array}{c}-0.414^{\star *} \\
(-2.24)\end{array}$ & $\begin{array}{c}-0.624^{* \star *} \\
(-6.43)\end{array}$ & $\begin{array}{c}-0.653 \text { *** } \\
(-6.75)\end{array}$ & $\begin{array}{l}-0.333 \\
(-1.53)\end{array}$ \\
\hline $\ln (M / B)$ & $\begin{array}{l}0.271 \text { ** } \\
(2.09)\end{array}$ & $\begin{array}{l}0.294 \text { ** } \\
(2.02)\end{array}$ & $\begin{array}{l}0.055 \\
(0.32)\end{array}$ & $\begin{array}{l}-0.022 \\
(-0.27)\end{array}$ & $\begin{array}{l}0.011 \\
(0.14)\end{array}$ & $\begin{array}{l}-0.237 \text { * } \\
(-1.73)\end{array}$ \\
\hline Debt & $\begin{array}{l}-0.000 \\
(-0.17)\end{array}$ & $\begin{array}{l}-0.004 \\
(-0.89)\end{array}$ & $\begin{array}{l}0.014 \\
(1.33)\end{array}$ & $\begin{array}{l}0.015^{*} \\
(1.72)\end{array}$ & $\begin{array}{l}0.011 \\
(1.29)\end{array}$ & $\begin{array}{l}0.030 \\
(1.41)\end{array}$ \\
\hline VROA & $\begin{array}{l}-0.184 \\
(-0.34)\end{array}$ & $\begin{array}{l}-0.426 \\
(-0.76)\end{array}$ & $\begin{array}{l}-0.294 \\
(-0.14)\end{array}$ & $\begin{array}{l}0.482 \\
(0.97)\end{array}$ & $\begin{array}{l}0.516 \\
(1.04)\end{array}$ & $\begin{array}{l}-0.736 \\
(-0.53)\end{array}$ \\
\hline $\ln$ (Analy) & $\begin{array}{c}-0.279 * \star \\
(-2.39) \\
\end{array}$ & $\begin{array}{c}-0.287 * * \\
(-2.22) \\
\end{array}$ & $\begin{array}{l}-0.119 \\
(-0.61) \\
\end{array}$ & $\begin{array}{l}-0.257 * \\
(-1.75) \\
\end{array}$ & $\begin{array}{l}-0.308 \text { ** } \\
(-2.21)\end{array}$ & $\begin{array}{l}0.054 \\
(0.13)\end{array}$ \\
\hline $\ln (\mathrm{VOL})$ & $\begin{array}{c}-0.121 \text { ** } \\
(-2.08)\end{array}$ & $\begin{array}{c}-0.168 * * * \\
(-2.67)\end{array}$ & $\begin{array}{l}0.041 \\
(0.34)\end{array}$ & $\begin{array}{l}0.062 \\
(0.31)\end{array}$ & $\begin{array}{l}0.133 \\
(0.88)\end{array}$ & $\begin{array}{l}-0.131 \\
(-0.25)\end{array}$ \\
\hline Zeros & $\begin{array}{c}0.034^{\star \star \star} \\
(6.24)\end{array}$ & $\begin{array}{c}0.037^{\star * *} \\
(5.74)\end{array}$ & $\begin{array}{c}0.036 \text { *** } \\
(4.01)\end{array}$ & $\begin{array}{l}-0.014 \\
(-1.23) \\
\end{array}$ & $\begin{array}{l}-0.008 \\
(-0.83) \\
\end{array}$ & $\begin{array}{l}-0.030 \\
(-0.99) \\
\end{array}$ \\
\hline Fixed eff. $(i, t)$ & Yes & Yes & Yes & Yes & Yes & Yes \\
\hline Observations & 1,597 & 1,304 & 400 & 1,597 & 1,304 & 400 \\
\hline Individuals & 233 & 191 & 60 & 233 & 191 & 60 \\
\hline Within- $R^{2}$ & $19.81 \%$ & $22.61 \%$ & $19.46 \%$ & $16.56 \%$ & $20.00 \%$ & $15.83 \%$ \\
\hline \multicolumn{7}{|c|}{ Panel B - Institutional investors and the information flow (II = hII) } \\
\hline \multirow{3}{*}{$\begin{array}{l}\text { Independent } \\
\text { variables }\end{array}$} & \multicolumn{3}{|c|}{ Dependent variable: NSync } & \multicolumn{3}{|c|}{ Dependent variable: BASP } \\
\hline & \multicolumn{3}{|c|}{$\mathrm{H} 2: \beta_{1}>0$} & \multicolumn{3}{|c|}{$\mathrm{H} 2: \beta_{1}<0$} \\
\hline & $\begin{array}{l}\text { The most } \\
\text { liquid ones } \\
\text { (1) }\end{array}$ & $\begin{array}{c}\text { ON } \\
\text { stocks } \\
(2)\end{array}$ & $\begin{array}{c}\text { PN } \\
\text { stocks } \\
(3)\end{array}$ & $\begin{array}{l}\text { The most } \\
\text { liquid ones } \\
\text { (4) }\end{array}$ & $\begin{array}{c}\text { ON } \\
\text { stocks } \\
\text { (5) }\end{array}$ & $\begin{array}{c}\text { PN } \\
\text { stocks } \\
(6)\end{array}$ \\
\hline hll & $\begin{array}{c}-0.003^{* *} \\
(-2.13)\end{array}$ & $\begin{array}{l}-0.002 \\
(-1.30)\end{array}$ & $\begin{array}{l}-0.006 \\
(-1.64)\end{array}$ & $\begin{array}{l}-0.001 \\
(-0.59)\end{array}$ & $\begin{array}{l}-0.000 \\
(-0.07)\end{array}$ & $\begin{array}{l}-0.003 \\
(-0.37)\end{array}$ \\
\hline Fixed eff. $(i, t)$ & Yes & Yes & Yes & Yes & Yes & Yes \\
\hline Within- $R^{2}$ & $20.07 \%$ & $22.69 \%$ & $18.99 \%$ & $16.17 \%$ & $19.87 \%$ & $14.88 \%$ \\
\hline
\end{tabular}

$\star, * \star$, and $* \star \star$ indicate significance at 10\%, 5\%, and 1\%, respectively.

Source: Elaborated by the authors. 
Thus, there is firm-level support for the empirical evidence presented by Dang et al. (2018) that there is a higher positive association between institutional ownership and stock liquidity in countries with opaque information environments or with poor institutional characteristics. PN stocks have characteristics that are consistent with lower transparency and weak property rights (Leal, Silva, \& Valadares, 2002).

The size coefficient is negative in all samples. This relationship is expected for NSync, and it indicates that larger firms have a greater weight in market indices (Gul, Kim, \& Qiu, 2010). For the bid-ask spread regression, the negative coefficient of size $(\ln (M V))$ indicates that the largest companies have lower information asymmetry and lower illiquidity. The market-to-book $(\operatorname{In}(M / B))$ is positive in the complete sample and for ON when the dependent variable is NSync, but it is not significant for PN (except for the negative coefficient when the dependent variable is BASP). These coefficients suggest that stocks with high growth potential (i. e., high Market-to-Book) are less synchronized with the rest of the market (Gul at al., 2010).

Finally, analysts' coverage (Analy) presents a negative coefficient for most liquid stocks and the ON stocks. The positive relationship between the number of analysts and the return synchronicity is largely documented in the literature. The most widely accepted explanation for this relationship is that analysts disseminate much more news about industry and markets than about firm-specific information (Piotroski \& Roulstone, 2004). They are associated with a low bid-ask spread.

Panel B exposes the test with the alternative variable hII. For this variable, the findings are conflicting with those exposed for nII. One possible explanation is that competition among institutional investors is essential to improve market efficiency, but most institutional investors claim that the threat of liquidation is only valid when they have at least $5-10 \%$ of the company's stocks (McCahery et al., 2016). In this scenario, extreme fragmentation of ownership may mitigate the strength of this kind of governance. The next test will cover this non-linear relationship.

\subsubsection{Non-linear relationship between competition and price efficiency}

Now, we test the non-linear relation between institutional investor's competition and price efficiency (H2a). To do that, we add a quadratic term on variable $I I$. The control variables are the same as in equation 8 . If the concave (convex) relationship holds, it is expected that $\beta_{1}$ (II) shows a posi- 
tive (negative) coefficient and $\beta_{2}\left(I^{2}\right)$ shows a negative (positive) coefficient when the dependent variable is NSync (BASP).

Figure 4.2.1.1 shows the estimated coefficients using the quadratic term. Due to the lack of space, we decided to do not tabulate the control variables. In panel A, there is no evidence of a non-linear relationship between the number of institutional investors and NSync. However, there is a convex relationship between the number of institutional investors and the bid-ask spread: when the number of institutional investors rises, there is a reduction of the bid-ask spread, but this bid-ask starts to grow at a certain point. This behavior is promoted by PN stocks (column 6).

Using the minimum and the maximum number of institutional investors ( 0 to 26 for the most liquid stocks and 0 to 25 for the PN ones), we can predict that the optimal number of institutional investors is 14 for the most liquid sample and 12 for the PN sample. There is no significant relationship when we employ the hII measure (panel B).

\section{(Figure 4.2.1.1)}

INSTITUTIONAL INVESTORS AND THE INFORMATION FLOW

\begin{tabular}{|c|c|c|c|c|c|c|}
\hline \multicolumn{7}{|c|}{ Panel A - Institutional investors and the information flow $(I I=\ln (n I I))$} \\
\hline \multirow{3}{*}{$\begin{array}{l}\text { Independent } \\
\text { variables }\end{array}$} & \multirow{2}{*}{\multicolumn{3}{|c|}{$\begin{array}{c}\text { Dependent variable: NSync } \\
\text { HZa: } \beta_{1}>0^{\wedge} \beta_{2}<0\end{array}$}} & \multirow{2}{*}{\multicolumn{3}{|c|}{$\begin{array}{c}\text { Dependent variable: } B A S P \\
\qquad \mathrm{H} 2: \beta_{1}<0^{\wedge} \beta_{2}>0\end{array}$}} \\
\hline & & & & & & \\
\hline & $\begin{array}{l}\text { The most } \\
\text { liquid ones } \\
\text { (1) }\end{array}$ & $\begin{array}{l}\text { ON } \\
\text { stocks } \\
(2)\end{array}$ & $\begin{array}{l}\text { PN } \\
\text { stocks } \\
(3)\end{array}$ & $\begin{array}{l}\text { The most } \\
\text { liquid ones } \\
\text { (4) }\end{array}$ & $\begin{array}{l}\text { ON } \\
\text { stocks } \\
(5)\end{array}$ & $\begin{array}{l}\text { PN } \\
\text { stocks } \\
(6)\end{array}$ \\
\hline nll & $\begin{array}{l}0.008 \\
(0.24)\end{array}$ & $\begin{array}{l}0.015 \\
(0.43)\end{array}$ & $\begin{array}{l}0.078 \\
(1.21)\end{array}$ & $\begin{array}{c}-0.1111^{\star \star} \\
(-2.50)\end{array}$ & $\begin{array}{l}-0.057 \\
(-1.40)\end{array}$ & $\begin{array}{c}-0.249 \text { ** } \\
(-2.21)\end{array}$ \\
\hline$n \|^{2}$ & $\begin{array}{l}-0.000 \\
(-0.24)\end{array}$ & $\begin{array}{c}-0.003^{\star \star} \\
(-2.30)\end{array}$ & $\begin{array}{l}-0.000 \\
(-0.20)\end{array}$ & $\begin{array}{c}0.004^{\star \star \star} \\
(2.81)\end{array}$ & $\begin{array}{c}0.003 \text { * } \\
(1.72)\end{array}$ & $\begin{array}{c}0.010 \text { ** } \\
(2.60)\end{array}$ \\
\hline Fixed eff. $(i, t)$ & Yes & Yes & Yes & Yes & Yes & Yes \\
\hline Observations & 1,597 & 1,304 & 400 & 1,597 & 1,319 & 400 \\
\hline Individuals & 233 & 194 & 60 & 233 & 194 & 60 \\
\hline Within- $R^{2}$ & 19.80\% & 22.84\% & $19.35 \%$ & $16.63 \%$ & $20.04 \%$ & $16.23 \%$ \\
\hline
\end{tabular}




\section{(Figure 4.2.1.1 (conclusion))}

INSTITUTIONAL INVESTORS AND THE INFORMATION FLOW

\begin{tabular}{|c|c|c|c|c|c|c|}
\hline \multicolumn{7}{|c|}{ Panel B - Institutional Investors and the information flow $(I I=h I I)$} \\
\hline \multirow{3}{*}{$\begin{array}{l}\text { Independent } \\
\text { variables }\end{array}$} & \multirow{2}{*}{\multicolumn{3}{|c|}{$\begin{array}{l}\text { Dependent variable: NSync } \\
\qquad \mathrm{H} 2: \beta_{1}>0^{\wedge} \beta_{2}<0\end{array}$}} & \multirow{2}{*}{\multicolumn{3}{|c|}{$\begin{array}{c}\text { Dependent variable: BASP } \\
\qquad \mathrm{H} 2: \beta_{1}<0^{\wedge} \beta_{2}>0\end{array}$}} \\
\hline & & & & & & \\
\hline & $\begin{array}{l}\text { The most } \\
\text { liquid ones (1) }\end{array}$ & $\begin{array}{l}\text { ON } \\
\text { stocks } \\
(2)\end{array}$ & $\begin{array}{l}\text { PN } \\
\text { stocks } \\
\text { (3) }\end{array}$ & $\begin{array}{l}\text { The most } \\
\text { liquid ones (4) }\end{array}$ & $\begin{array}{l}\text { ON } \\
\text { stocks } \\
(5)\end{array}$ & $\begin{array}{l}\text { PN } \\
\text { stocks } \\
(6)\end{array}$ \\
\hline hll & $\begin{array}{l}-0.004 \\
(-0.89)\end{array}$ & $\begin{array}{l}-0.001 \\
(-0.33)\end{array}$ & $\begin{array}{l}-0.013 \\
(-1.16)\end{array}$ & $\begin{array}{l}0.003 \\
(0.57)\end{array}$ & $\begin{array}{l}-0.002 \\
(-0.34)\end{array}$ & $\begin{array}{c}0.022 \text { * } \\
(1.71)\end{array}$ \\
\hline$h \|^{2}$ & $\begin{array}{l}-0.000 \\
(-0.17)\end{array}$ & $\begin{array}{r}-0.000 \\
(0.05)\end{array}$ & $\begin{array}{l}-0.000 \\
(-0.68)\end{array}$ & $\begin{array}{l}0.000 \\
(0.95)\end{array}$ & $\begin{array}{l}0.000 \\
(-0.36)\end{array}$ & $\begin{array}{c}0.000 \text { ** } \\
(2.44)\end{array}$ \\
\hline Fixed eff. $(i, t)$ & Yes & Yes & Yes & Yes & Yes & Yes \\
\hline Within- $R^{2}$ & $20.07 \%$ & $22.69 \%$ & $19.07 \%$ & $16.21 \%$ & $19.88 \%$ & $15.46 \%$ \\
\hline
\end{tabular}

${ }^{*},{ }^{* *}$, and ${ }^{* * \star}$ indicate significance at 10\%, 5\%, and $1 \%$, respectively.

Source: Elaborated by the authors.

\subsection{Institutional investors and operational performance}

In this section, we analyzed whether institutional investors are important to operational performance $(\mathrm{H} 3)$, using equation 9 , in which $R O A$ is the return on assets; and Control is the vector of control variables for the operation performance.

$$
R O A_{i, t}=\beta_{0}+\beta_{1} I I_{i, t}+\sum_{k} \beta_{k} \text { Control }_{i, t}+\varepsilon_{i, t}
$$

Following Fang et al. (2009), we segmented the sample into four subsamples according to the information efficiency levels: low NSync (below the NSync median) and high NSync (equal to or above the NSync median). The same pattern is followed for the bid-ask spread (BASP). The intuition is that, if institutional investors increase price efficiency and this relationship is motivated by the governance through trading, it is expected that the number of institutions will be more relevant for performance in firms with higher information incorporation (NSync) and lower bid-ask spread (BASP).

Panel A of Figure 4.3.1 demonstrates the irrelevance of the number of institutional investors $(n I I)$ in the firm's profitability. These findings are like 
the evidence on Fang et al.'s (2009) that institutional investors do not increase the performance of companies in the US market. However, panel B shows support for the H3: for ON stocks with more information incorporation, there is evidence that the competition between institutional investors is associated with firm performance. In firms with low NSync, the effect is the opposite. This behavior was not found using BASP as the dependent variable (to preserve space, we did not tabulate these results).

\section{(Figure 4.3.1) \\ INCORPORATION OF INFORMATION, INSTITUTIONAL INVESTORS, AND PERFORMANCE}

\begin{tabular}{|c|c|c|c|c|c|c|}
\hline \multicolumn{7}{|c|}{ Panel A - NSync levels, institutional investors (In(nII)) and firm' operational performance } \\
\hline \multirow{4}{*}{$\begin{array}{l}\text { Independent } \\
\text { variables }\end{array}$} & \multicolumn{6}{|c|}{ Dependent variable: $R O A$} \\
\hline & \multicolumn{6}{|c|}{$\mathrm{H} 3: \beta_{1}>0^{a}$} \\
\hline & \multicolumn{3}{|c|}{ Sample: high NSync ( $\geq$ Median) } & \multicolumn{3}{|c|}{ Sample: low NSync (< Median) } \\
\hline & $\begin{array}{l}\text { The most } \\
\text { liquid ones } \\
\text { (1) }\end{array}$ & $\begin{array}{c}\text { ON } \\
\text { stocks } \\
(2)\end{array}$ & $\begin{array}{c}\text { PN } \\
\text { stocks } \\
(3)\end{array}$ & $\begin{array}{l}\text { The most } \\
\text { liquid ones } \\
\text { (4) }\end{array}$ & $\begin{array}{c}\text { ON } \\
\text { stocks } \\
(5)\end{array}$ & $\begin{array}{c}\text { PN } \\
\text { stocks } \\
(6)\end{array}$ \\
\hline $\ln (n \mid l)$ & $\begin{array}{l}0.149 \\
(0.16)\end{array}$ & $\begin{array}{l}0.619 \\
(0.52)\end{array}$ & $\begin{array}{l}-2.177 \\
(-1.58)\end{array}$ & $\begin{array}{l}0.381 \\
(0.62)\end{array}$ & $\begin{array}{l}0.056 \\
(0.08)\end{array}$ & $\begin{array}{l}0.719 \\
(1.01)\end{array}$ \\
\hline $\ln (M V)$ & $\begin{array}{c}2.797 \text { ** } \\
(2.60)\end{array}$ & $\begin{array}{l}1.737 \\
(1.42)\end{array}$ & $\begin{array}{l}2.884 \\
(1.56)\end{array}$ & $\begin{array}{c}2.645 \text { ** } \\
(2.43)\end{array}$ & $\begin{array}{c}2.628 \text { ** } \\
(2.15)\end{array}$ & $\begin{array}{c}5.293^{\text {** }} \\
(2.58)\end{array}$ \\
\hline $\ln (M / B)$ & $\begin{array}{l}0.566 \\
(0.46)\end{array}$ & $\begin{array}{l}1.077 \\
(0.78)\end{array}$ & $\begin{array}{l}0.594 \\
(0.55)\end{array}$ & $\begin{array}{c}2.884 * * * \\
(4.34)\end{array}$ & $\begin{array}{c}3.188 \text { *** } \\
(4.70)\end{array}$ & $\begin{array}{l}-0.384 \\
(-0.18)\end{array}$ \\
\hline Debt & $\begin{array}{l}-0.083 \\
(-1.34)\end{array}$ & $\begin{array}{l}-0.054 \\
(-0.77)\end{array}$ & $\begin{array}{c}-0.171 \text { ** } \\
(-2.50)\end{array}$ & $\begin{array}{l}-0.028 \\
(-0.69)\end{array}$ & $\begin{array}{l}-0.031 \\
(-0.70)\end{array}$ & $\begin{array}{l}-0.009 \\
(-0.12)\end{array}$ \\
\hline Zeros & $\begin{array}{l}0.003 \\
(0.10)\end{array}$ & $\begin{array}{l}-0.030 \\
(-0.80)\end{array}$ & $\begin{array}{l}0.068 \\
(1.59)\end{array}$ & $\begin{array}{l}-0.148 \\
(-1.49)\end{array}$ & $\begin{array}{l}-0.137 \\
(-1.06)\end{array}$ & $\begin{array}{l}0.093 \\
(1.25)\end{array}$ \\
\hline Fixed eff. $(i, t)$ & Yes & Yes & Yes & Yes & Yes & Yes \\
\hline Observations & 682 & 552 & 157 & 915 & 752 & 243 \\
\hline Individuals & 116 & 95 & 30 & 117 & 96 & 30 \\
\hline Within- $R^{2}$ & $7.43 \%$ & $6.41 \%$ & 18.84\% & $29.24 \%$ & $36.56 \%$ & $20.03 \%$ \\
\hline
\end{tabular}




\section{(Figure 4.3.1 (conclusion))}

\section{INCORPORATION OF INFORMATION, INSTITUTIONAL INVESTORS, AND PERFORMANCE}

\begin{tabular}{|c|c|c|c|c|c|c|}
\hline \multicolumn{7}{|c|}{ Panel B - NSync levels, institutional investors (hIl) and firm' operational performance } \\
\hline \multirow{4}{*}{$\begin{array}{l}\text { Independent } \\
\text { variables }\end{array}$} & \multicolumn{6}{|c|}{ Dependent variable: $R O A$} \\
\hline & \multicolumn{6}{|c|}{$\mathrm{H} 3: \beta^{1}>0^{a}$} \\
\hline & \multicolumn{3}{|c|}{ Sample: high NSync ( $\geq$ Median) } & \multicolumn{3}{|c|}{ Sample: low NSync ( < Median) } \\
\hline & $\begin{array}{l}\text { The most } \\
\text { liquid ones } \\
\text { (1) }\end{array}$ & $\begin{array}{c}\text { ON } \\
\text { stocks } \\
(2)\end{array}$ & $\begin{array}{c}\text { PN } \\
\text { stocks } \\
(3)\end{array}$ & $\begin{array}{l}\text { The most } \\
\text { liquid ones } \\
\text { (4) }\end{array}$ & $\begin{array}{c}\text { ON } \\
\text { stocks } \\
(5)\end{array}$ & $\begin{array}{c}\text { PN } \\
\text { stocks } \\
(6)\end{array}$ \\
\hline hll & $\begin{array}{l}0.032 \\
(1.59)\end{array}$ & $\begin{array}{c}0.056 \text { ** } \\
(1.99)\end{array}$ & $\begin{array}{l}-0.026 \\
(-0.76)\end{array}$ & $\begin{array}{c}-0.027 \text { ** } \\
(-2.06)\end{array}$ & $\begin{array}{c}-0.025 \text { * } \\
(-1.79)\end{array}$ & $\begin{array}{l}0.003 \\
(0.20)\end{array}$ \\
\hline Fixed eff. $(i, t)$ & Yes & Yes & Yes & Yes & Yes & Yes \\
\hline Within- $R^{2}$ & $7.84 \%$ & $7.34 \%$ & $18.26 \%$ & 29.68\% & $37.02 \%$ & $19.91 \%$ \\
\hline
\end{tabular}

\subsubsection{The role of executive compensation}

The failure to observe the institutional investors' impact on performance raises some conjectures:

- the efficiency gains may not have a significant effect on the firms' performance because there are no efficient contracts that align managers' remuneration to stock returns (Edmans et al., 2013). According to Hofmeister (2018), firms with low governance do not have optimal executive compensations. The New Market rules do not permit the issuance of stocks without voting rights, which implies that the preferred stocks (PN) of this study are stocks outside the New Market segment and, consequently, without managers' remuneration strongly linked to stock performance;

- the performance gain can occur in long-term periods not addressed in this study.

Unfortunately, there is no easy way to test the second conjecture, but we can test the first one. First, we calculated the mean value of NSync and BASP 
of each firm for the sample period. Let's call these two new variables $\overline{\text { NSync }}$ and $\overline{B A S P}$. Then, we used the median of $\overline{N S y n c}$ and $\overline{B A S P}$ to separate firms on high or low NSync and High or Low BASP.

In a second step, we calculated the percentage of executive compensation that comes from the firm performance to split firms on high and low executive compensation, using the same mean and split technique. The variable remuneration (Remu) is the total variable income of company directors divided by the total directors' remuneration.

$$
\text { Remu }=\frac{\text { Variable remuneration from profit sharing }}{\text { Total remuneration }}
$$

Figure 4.3.1.1 shows the summary statistics of the main variables for each subsample, in which, HNHR (LNLR) is the high (low) NSync and high (low) Remu sample, and HBHR (LBLR) is the high (low) BASP and high (low) Remu sample. All samples follow this kind of logic (see the note in Figure 4.3.1.1 for more details).

\section{(Figure 4.3.1.1)}

SUBSAMPLES SUMMARY STATISTICS

\begin{tabular}{lrrrrrrrr}
\hline \multicolumn{7}{c}{ Panel A: the most liquid ones } \\
\hline HNHR & HNLR & LNHR & LNLR & HBHR & HBLR & LBHR & LBLR \\
\hline NSync & 4.406 & 4.412 & 1.443 & 1.688 & 2.055 & 2.734 & 2.769 & 3.244 \\
\hline BASP & 2.803 & 3.594 & 3.332 & 3.463 & 3.908 & 4.611 & 2.558 & 2.447 \\
\hline Remu & 19.895 & 0.000 & 23.499 & 0.276 & 19.083 & 0.000 & 22.159 & 0.021 \\
\hline ROA & 7.552 & 3.591 & 9.854 & 8.841 & 7.993 & 2.940 & 10.666 & 8.726 \\
\hline nll & 3.773 & 3.194 & 4.571 & 3.462 & 4.228 & 3.645 & 4.290 & 2.966 \\
\hline hll & -51.522 & -42.895 & -48.187 & -46.488 & -47.253 & -45.219 & -49.419 & -45.848 \\
\hline & & & & Panel A: ONs & & & \\
\hline & HNHR & HNLR & LNHR & LNLR & HBHR & HBLR & LBHR & LBLR \\
\hline NSync & 3.900 & 4.208 & 1.440 & 1.627 & 1.998 & 2.618 & 2.526 & 2.963 \\
\hline BASP & 2.934 & 3.604 & 3.376 & 3.490 & 3.968 & 4.512 & 2.600 & 2.550 \\
\hline Remu & 21.911 & 0.000 & 22.139 & 0.200 & 18.264 & 0.000 & 22.547 & 0.000 \\
\hline
\end{tabular}




\section{(Figure 4.3.1.1 (conclusion))}

\section{SUBSAMPLES SUMMARY STATISTICS}

\begin{tabular}{|c|c|c|c|c|c|c|c|c|}
\hline \multicolumn{9}{|c|}{ Panel A: ONs } \\
\hline & HNHR & HNLR & LNHR & LNLR & HBHR & HBLR & LBHR & LBLR \\
\hline$R O A$ & 7.147 & 4.413 & 10.636 & 8.445 & 8.005 & 3.154 & 10.706 & 9.894 \\
\hline$n l l$ & 3.754 & 3.460 & 4.480 & 3.339 & 3.937 & 3.721 & 4.307 & 3.135 \\
\hline hll & -56.225 & -44.885 & -49.156 & -46.796 & -48.640 & -45.627 & -54.619 & -45.026 \\
\hline \multicolumn{9}{|c|}{ Panel B: PNs } \\
\hline & HNHR & HNLR & LNHR & LNLR & HBHR & HBLR & LBHR & LBLR \\
\hline NSync & 5.486 & 5.606 & 1.778 & 2.377 & 2.416 & 3.045 & 3.787 & 4.612 \\
\hline BASP & 2.162 & 2.978 & 3.009 & 3.436 & 3.418 & 4.518 & 2.121 & 1.905 \\
\hline Remu & 19.816 & 0.000 & 25.253 & 0.112 & 25.811 & 0.000 & 22.441 & 0.258 \\
\hline$R O A$ & 8.579 & 1.580 & 9.478 & 5.288 & 8.255 & 1.439 & 9.885 & 6.287 \\
\hline$n l l$ & 3.239 & 1.952 & 5.030 & 3.375 & 4.957 & 3.282 & 3.924 & 2.250 \\
\hline hll & -51.953 & -54.518 & -41.149 & -36.462 & -40.928 & -46.131 & -45.875 & -45.952 \\
\hline
\end{tabular}

HNHR = high NSync and high Remu; HNLR = high NSync and low Remu; LNHR = low NSync and high Remu; LNLR = low NSync and low Remu; HBHR = High BASP and high Remu; HBLR = high BASP and low Remu; LBHR = low BASP and high Remu; LBLR = low BASP and low Remu.

Source: Elaborated by the authors.

Figure 4.3.1.2 shows the results of equation 9 for the most liquid stocks subsample. We did not test equation 9 on the $\mathrm{ON}$ and PN samples because of small sample data. We chose not to tabulate the control variables to preserve space. In panel A, we can see that, in firms with high information incorporation and high variable executive compensation, the growth of the number of institutional investors has a positive effect on ROA (column 1). This scenario cannot be observed on low NSync samples (columns 3 and 4). In panel $\mathrm{B}$, the higher the competition on high NSync samples, the higher the $R O A$. This relationship seems to be independent of variable remuneration. Finally, a puzzle emerges in panel D: in the sample of high bid-ask and low remuneration, the number of institutional investors is associated with higher ROAs. This is not a huge concern, since the coefficient is positive. Due to the lack of space, we did not tabulate the ONs and PNs subsample estimates, but the results exposed in Figure 4.3.1.1 are driven by ONs stocks. 


\section{(Figure 4.3.1.2)}

INCORPORATION OF INFORMATION, INSTITUTIONAL INVESTORS, PERFORMANCE, AND REMUNERATION

\begin{tabular}{|c|c|c|c|c|}
\hline \multicolumn{5}{|c|}{ Panel A - NSync levels, institutional investors (In( $n I I))$ and firm' operational performance } \\
\hline \multirow{3}{*}{$\begin{array}{l}\text { Independent } \\
\text { variables }\end{array}$} & \multicolumn{4}{|c|}{ Dependent variable: $R O A$} \\
\hline & \multicolumn{4}{|c|}{$\mathrm{H} 3: \beta_{1}>0$} \\
\hline & $\begin{array}{l}\text { HNHR } \\
(1)\end{array}$ & $\begin{array}{l}\text { HNLR } \\
\text { (2) }\end{array}$ & $\begin{array}{l}\text { LNHR } \\
(3)\end{array}$ & $\begin{array}{l}\text { LNLR } \\
(4)\end{array}$ \\
\hline $\ln (n \mid l)$ & $\begin{array}{l}3.044 \text { * } \\
(1.94)\end{array}$ & $\begin{array}{l}-1.045 \\
(-0.84)\end{array}$ & $\begin{array}{l}0.597 \\
(0.57)\end{array}$ & $\begin{array}{l}-0.176 \\
(-0.21)\end{array}$ \\
\hline Fixed eff. (i, t) & Yes & Yes & Yes & Yes \\
\hline Observations & 225 & 314 & 413 & 387 \\
\hline Individuals & 36 & 52 & 50 & 51 \\
\hline Within- $R^{2}$ & $32.35 \%$ & $15.36 \%$ & $30.66 \%$ & $33.67 \%$ \\
\hline \multicolumn{5}{|c|}{ Panel B - NSync levels, institutional investors $(\operatorname{In}(n I I))$ and firm' operational performance } \\
\hline \multirow{3}{*}{$\begin{array}{l}\text { Independent } \\
\text { variables }\end{array}$} & \multicolumn{4}{|c|}{ Dependent variable: $R O A$} \\
\hline & \multicolumn{4}{|c|}{$\mathrm{H} 3: \beta_{1}>0$} \\
\hline & $\begin{array}{l}\text { HNHR } \\
(1)\end{array}$ & $\begin{array}{l}\text { HNLR } \\
\text { (2) }\end{array}$ & $\begin{array}{l}\text { LNHR } \\
(3)\end{array}$ & $\begin{array}{l}\text { LNLR } \\
(4)\end{array}$ \\
\hline hll & $\begin{array}{c}0.053^{*} \\
(1.68)\end{array}$ & $\begin{array}{c}0.057 * \\
(1.89)\end{array}$ & $\begin{array}{l}-0.030 \\
(-1.22)\end{array}$ & $\begin{array}{l}-0.023 \\
(-1.66) \\
\end{array}$ \\
\hline Fixed eff. (i, t) & Yes & Yes & Yes & Yes \\
\hline Observations & 225 & 314 & 413 & 387 \\
\hline Individuals & 36 & 52 & 50 & 51 \\
\hline Within-R2 & $31.83 \%$ & $16.21 \%$ & $30.98 \%$ & $34.15 \%$ \\
\hline \multicolumn{5}{|c|}{ Panel C - BASP levels, institutional investors (In(nII)) and firm' operational performance } \\
\hline \multirow{3}{*}{$\begin{array}{c}\text { Independent } \\
\text { variables }\end{array}$} & \multicolumn{4}{|c|}{ Dependent variable: $R O A$} \\
\hline & \multicolumn{4}{|c|}{$\mathrm{H} 3: \beta_{1}>0$} \\
\hline & $\begin{array}{l}\text { HBHR } \\
(1)\end{array}$ & $\begin{array}{l}\text { HBLR } \\
\text { (2) }\end{array}$ & $\begin{array}{l}\text { LBHR } \\
\text { (3) }\end{array}$ & $\begin{array}{l}\text { LBLR } \\
(4)\end{array}$ \\
\hline $\ln (n \mid l)$ & $\begin{array}{l}1.808 \\
(1.45)\end{array}$ & $\begin{array}{l}-1.665 \\
(-1.42)\end{array}$ & $\begin{array}{l}0.181 \\
(0.17)\end{array}$ & $\begin{array}{l}-0.196 \\
(-0.19)\end{array}$ \\
\hline
\end{tabular}




\section{(Figure 4.3.1.2 (conclusion))}

INCORPORATION OF INFORMATION, INSTITUTIONAL INVESTORS, PERFORMANCE, AND REMUNERATION

\begin{tabular}{|c|c|c|c|c|}
\hline \multicolumn{5}{|c|}{ Panel C - BASP levels, institutional investors $(\operatorname{In}(n I I))$ and firm' operational performance } \\
\hline \multirow{3}{*}{$\begin{array}{l}\text { Independent } \\
\text { variables }\end{array}$} & \multicolumn{4}{|c|}{ Dependent variable: $R O A$} \\
\hline & \multicolumn{4}{|c|}{$\mathrm{H} 3: \beta_{1}>0$} \\
\hline & $\begin{array}{l}\text { HBHR } \\
(1)\end{array}$ & $\begin{array}{l}\text { HBLR } \\
(2)\end{array}$ & $\begin{array}{l}\text { LBHR } \\
\text { (3) }\end{array}$ & $\begin{array}{l}\text { LBLR } \\
(4)\end{array}$ \\
\hline Fixed eff. $(i, t)$ & Yes & Yes & Yes & Yes \\
\hline Observations & 320 & 319 & 368 & 332 \\
\hline Individuals & 41 & 48 & 50 & 50 \\
\hline Within- $R^{2}(\%)$ & $37.85 \%$ & $19.18 \%$ & $21.36 \%$ & 1471 \\
\hline \multicolumn{5}{|c|}{ Panel D - BASP levels, institutional investors $(\ln (n I l))$ and firm' operational performance } \\
\hline \multirow{3}{*}{$\begin{array}{l}\text { Independent } \\
\text { variables }\end{array}$} & \multicolumn{4}{|c|}{ Dependent variable: $R O A$} \\
\hline & \multicolumn{4}{|c|}{$\mathrm{H} 3: \beta_{1}>0$} \\
\hline & $\begin{array}{l}\mathrm{HBHR} \\
(1)\end{array}$ & $\begin{array}{l}\text { HBLR } \\
(2)\end{array}$ & $\begin{array}{l}\text { LBHR } \\
\text { (3) }\end{array}$ & $\begin{array}{l}\text { LBLR } \\
(4)\end{array}$ \\
\hline hll & $\begin{array}{l}-0.022 \\
(-0.71)\end{array}$ & $\begin{array}{c}0.059 * \star \\
(2.18)\end{array}$ & $\begin{array}{l}-0.017 \\
(-0.69)\end{array}$ & $\begin{array}{l}-0.003 \\
(-0.18)\end{array}$ \\
\hline Fixed eff. (i, t) & Yes & Yes & Yes & Yes \\
\hline Observations & 320 & 319 & 368 & 332 \\
\hline Individuals & 41 & 48 & 50 & 50 \\
\hline Within-R $R^{2}(\%)$ & $37.29 \%$ & $19.84 \%$ & $21.53 \%$ & $14.71 \%$ \\
\hline
\end{tabular}

* and ** indicate significance at $10 \%$ and $5 \%$, respectively.

Source: Elaborated by the authors.

\section{CONCLUSIONS}

This study analyzed whether theories of governance through trading are valid in the Brazilian stock market. We developed three hypotheses to guide the empirical analysis.

- The central assumption of corporate governance through trading theories is that investors are informed and compete for the informational advantage profit - this assumption was tested in the first hypothesis (H1). 
- Such a negotiation raises price efficiency by incorporating hitherto private information into prices $(\mathrm{H} 2)$. However, this relation is not linear, and there is an optimum amount of competition ( $\mathrm{H} 2 \mathrm{a})$.

- This mechanism would make the pricing system more aligned with company fundamentals and would lead to higher performance (H3).

Our findings can be summarized in five points:

1) The number of institutional investors is not related to returns. One possible explanation is that most of the sample's institutions may have no information advantage and are passive investors who do not compete for information.

2) The greater number of institutions increases the incorporation of firmspecific information to prices, increasing pricing efficiency. This relationship is more evident in PN shares, whose ownership rights are reduced.

3) There is evidence that the price efficiency gains are maximized when there are approximately 12 institutional investors on PN stocks and 14 institutional investors for the sample of the most liquid ones.

4) There is weak evidence that the number of institutional investors is positively associated with performance, and its behavior is concentrated among ON stocks. This finding can be explained by the weak link between stock performance and the executives' pay-for-performance remuneration. PN shares have a greater possibility of information efficiency gains, but are issued by firms whose stock prices do not promote change in managers' salaries.

5) When we take the variable remuneration into account, the number of institutional investors is positively associated with performance.

These findings have two main implications. The first one is that the presence of institutional investors is vital to raise the stock price efficiency levels, either through the greater incorporation of information or through the reduction of the bid-ask spread. Policies that allow capital inflows and ensure greater property protection are beneficial for market efficiency. The second implication is directly associated with the first: there is no evidence that the greater amount of institutions implies an increase in the performance of the firms if there is no variable remuneration plan.

These findings give rise to conjectures that the lack of association between executive rewards and stock performance can mitigate potential efficiency gains and prevent trading or the threat of liquidation from being an effective 
governance mechanism in these firms. Therefore, in the case of companies with a dispersion property structure, it is advisable to adopt measures that increase the stock liquidity and the adoption of an executive payment linked to the stock performance, as proposed by Edmans et al. (2013).

Finally, this study has some limitations. The database adopted to study the ownership structure of Brazilian companies did not provide precise information, such as the firms' number of identification (CNPJ). This limitation was mitigated using keywords associated with institutional investors. However, this may raise criticism about the identification effectiveness and its replicability.

\section{GOVERNANÇA VIA NEGOCIAÇÃO DE AÇÕES NO BRASIL: EVIDÊNCIAS COM INVESTIDORES INSTITUCIONAIS}

\section{RESUMO}

Objetivo: Este artigo analisa a viabilidade da negociação de ações como um mecanismo para promover a governança corporativa, abordando seus efeitos sobre retornos anormais, informações e desempenho das empresas.

Originalidade/valor: A competição entre investidores institucionais é importante para aumentar a eficiência informacional dos preços das ações. Políticas que permitem a entrada de capital, aumentam a liquidez e fortalecem a relação entre os salários dos gestores com o desempenho das ações são benéficas para reforçar a eficiência do mercado.

Design/metodologia/abordagem: Realizaram-se testes de hipóteses usando regressões de dados em painel com 233 ações entre dezembro de 2009 e dezembro de 2017 da Thomson Eikon, Economatica e ComDinheiro.

Resultados: O número de investidores institucionais não está relacionado a retornos anormais. Porém, o número de investidores institucionais aumenta a incorporação de informações específicas da empresa nos preços das ações, o que eleva a eficiência dos preços no mercado de ações. Essa relação é mais forte entre as ações preferenciais (PN), mas esse mecanismo ainda não é suficiente para aumentar o desempenho operacional. Apesar do possível aumento na eficiência do preço das ações, os investidores não poderão adotar esse mecanismo para exercer governança se não houver remuneração vinculada ao desempenho. 


\section{PALAVRAS-CHAVE}

Governança corporativa. Liquidação. Informatividade dos preços das ações. Investidor institucional. Bid-ask spread.

\section{REFERENCES}

Akins, B. K., Ng, J., \& Verdi, R. S (2012). Investor competition over information and the pricing of information asymmetry. The Accounting Review, 87(1), 35-58. doi:10.2308/accr-10157

Brogaard, J., Li, D., \& Xia, Y. (2017). Stock liquidity and default risk. Journal of Financial Economics, 124(3), 486-502. doi:10.1016/j.jfineco.2017.03.003

Chan, K., \& Hameed, A. (2006). Stock price synchronicity and analyst coverage in emerging markets. Journal of Financial Economics, 80(1), 115-147. doi:10.1016/j.jfineco.2005.03.010

Chen, Q., Goldstein, I., \& Jiang, W. (2007). Price informativeness and investment sensitivity to stock price. Review of Financial Studies, 20(3), 619-650. doi:10.1093/rfs/hhl024

Collin-Dufresne, P., \& Fos, V. (2015). Do prices reveal the presence of informed trading? Journal of Finance, 70(4), 1555-1582. doi:10.1111/ jofi. 1226

Cordeiro, R., \& Machado, M. A. V. (2013). Estratégia de valor ou de crescimento? Evidências empíricas no Brasil. Revista Brasileira de Gestão de Negócios, 15(46), 91-111. doi:10.7819/rbgn.v15i46.1170

Dang, T. L., Nguyen, T. H., Tran, N. T. A., \& Vo, T. T. A. (2018). Institutional ownership and stock liquidity: International evidence. Asia-Pacific Journal of Financial Studies, 47(1), 21-53. doi:10.1111/ajfs.12202

Easley, D., Hvidkjaer, S., \& O'Hara, M. (2002) Is information risk a determinant of asset returns? Journal of Finance, 57(5), 2185-2221. Retrieved from http://www.jstor.org/stable/3094509

Edmans, A., Fang, V. W., \& Zur, E. (2013). The effect of liquidity on governance. The Review of Financial Studies, 26(6), 1444-1482. doi:10.1093/rfs/hht012

Edmans, A., \& Holderness, C. G. (2017). Blockholders: A survey of theory and evidence. In B. Hermalin \& M. Weisbach, The handbook of corporate governance (Vol. 1). Amsterdam: Elsevier. 
Edmans, A., \& Manso, G. (2011). Governance through trading and intervention: A theory of multiple blockholders. The Review of Financial Studies, 24(7), 2395-2428. doi:10.1093/rfs/hhq145

Fama, E. F., \& French, K. (2006). Profitability, investment, and average returns. Journal of Financial Economics, 82, 491-518. doi:10.1016/j.jfineco. 2005.09.009

Fang, V. W., Noe, T. H. \& Tice, S. (2009). Stock market liquidity and firm value. Journal of Financial Economics, 94(1), 150-169. doi:10.1016/j.jfineco. 2008.08.007

Gallagher, D. R., Gardner, P. A., \& Swan, P. L. (2013). Governance through trading: Institutional swing trades and subsequent firm performance. Journal of Financial and Quantitative Analysis, 48(2), 427-458. doi:10.1017/ S0022109013000203

Girão, L. F. A. P. (2016) Competição por informações, ciclo de vida e custo do capital no Brasil. Tese de doutorado, Universidade Federal da Paraíba, João Pessoa, PB, Brasil. Retrieved from http://repositorio.unb.br/handle/10482/21143

Gul, F. A., Kim, J., \& Qiu, A. A. (2010). Ownership concentration, foreign shareholding, audit quality, and stock price synchronicity: Evidence from China. Journal of Financial Economics, 95(3), 425-442. doi:10.1016/j.jfineco. 2009.11.005

Hendershott, T., Livdan, D., \& Schürhoff, N. (2015). Are institutions informed about news? Journal of Financial Economics, 117(2), 249-287. doi:10.1016/ j.jfineco.2015.03.007

Hofmeister, P. (2018). Executive pay, firm performance, and shareholder return: The case of Brazilian public firms. Master dissertation, Fundação Getulio Vargas, São Paulo, SP, Brasil. Retrieved from http://hdl.handle.net/10438/20691

KPMG (2016). A governança corporativa e o mercado de capitais: Um panorama atual das empresas abertas, com base nos seus Formulários de Referência (11a ed.). São Paulo: KPMG. Retrieved from https://assets.kpmg.com/content/dam/ $\mathrm{kpmg} / \mathrm{br} / \mathrm{pdf} / 2016 / 12 /$ br-estudo-governanca-corporativa-2016-201711a-edicao-final.pdf

Kyle, A. S. (1985). Continuous auctions and insider trading. Econometrica, 53(6), 1315-1335. Retrieved from https://www.jstor.org/stable/1913210

Leal, R. P. C., Silva, A. L. C., \& Valadares, S. M. (2002). Estrutura de controle das companhias brasileiras de capital aberto. Revista de Administração Contemporânea, 6(1), 7-18. doi:10.1590/S1415-65552002000100002 
McCahery J., Sautner, Z., \& Starks, L. (2016). Behind the scenes: The corporate governance preferences of institutional investors. Journal of Finance, 71(6), 2905-2932. doi:10.1111/jofi.12393

Morck, R., Yeung, B., \& Yu, W. (2000). The information content of stock markets: Why do emerging markets have synchronous stock price movements? Journal of Financial Economics, 58(1), 215-260. doi:10.1016/S0304405X(00)00071-4

Piotroski, J. D., \& Roulstone, D. (2004). The influence of analysts, institutional investors, and insiders on the incorporation of market, industry, and firm-specific information into stock prices. Accounting Review, 79(4), 1119-1151. Retrieved from http://www.jstor.org/stable/4093088

Roll, R. (1988). “R2”. Journal of Finance, 43(3), 541-566. doi:10.1111/j.15406261.1988.tb04591.x

Shleifer, A., \& Vishny, R. (1986). Large shareholders and corporate control. Journal of Political Economy, 94(3), 461-488. Retrieved from https://www. jstor.org/stable/1833044

\section{) AUTHOR NOTES}

Lucas N. C. Vasconcelos, master by the Postgraduate Program in Administration, Federal University of Paraíba (UFPB); Orleans S. Martins, Ph.D by the Multi-Institutional and Interregional Postgraduate Program in Accounting, University of Brasília (UnB).

Lucas N. C. Vasconcelos is now professor at the Department of Finance and Accounting of the UFPB; Orleans S. Martins is now professor at the Department of Finance and Accounting of the UFPB.

Correspondence concerning this article should be addressed to Orleans S. Martins, Cidade Universitária, s/n, Castelo Branco, João Pessoa, Paraíba, Brazil, CEP 58.051-000.

E-mail: orleansmartins@yahoo.com.br

EDITORIAL BOARD

Editor-in-chief

Gilberto Perez

Associated Editor

Eduardo Kazuo Kayo

Technical Support

Vitória Batista Santos Silva
EDITORIAL PRODUCTION

$\begin{array}{ll}\begin{array}{l}\text { Publishing Coordination } \\ \text { Jéssica Dametta }\end{array} & \begin{array}{l}\text { Layout Designer } \\ \text { Emap }\end{array} \\ \begin{array}{l}\text { Editorial Intern } \\ \text { Paula Di Sessa Vavlis }\end{array} & \text { Graphic Designer } \\ & \text { Libro } \\ \text { Language Editor } & \\ \text { Daniel de Almeida Leão } & \end{array}$

